\section{Effects of a health program comprising reassurance, diet management, probiotics administration and regular exercise on symptoms and quality of life in patients with irritable bowel syndrome}

\author{
Magdy El-Salhy, ${ }^{1,2}$ Elli Lillebo,' \\ Astrid Reinemo, 'Lillian Salmelid, \\ Trygve Hausken'
}

'Section for Gastroenterology,

Department of Medicine, Stord

Helse-Fonna Hospital, Norway;

${ }^{2}$ Section for Gastroenterology, Institute

of Medicine, Bergen University, Norway

\section{Abstract}

Effects of a health program comprising reassurance and patient education, diet management, administration of probiotics and regular exercise on symptoms and quality of life in patients with IBS were investigated.

A total of 143 patients (95\% women and 5\% men), with an average age of 32 years (range, 18-58 years), were included in the study. Ninety-six of these patients had diarrhea and 47 had constipation as the predominant symptom. The patients went through a program combining reassurance and IBS education, guidance in diet management, intake of probiotics, and regular exercise. The patients were asked to complete the Birmingham IBS symptom score questionnaire, the SF-36 questionnaire and the IBS-quality of life (IBS-QoL) questionnaire before starting the program and three, six, 12 and 24 months after completing the program.

The total score of symptoms, as well as all the 3 dimensions (pain, diarrhea and constipation), were diminished significantly at all observation times after completing the program. The total score of quality of life, as assessed by the SF-36 questionnaire and by the IBS-QoL questionnaire, was significantly improved at all observation times after completing the program. This improvement included all health concepts of the SF-36 and all the domains of the IBS-QoL except physical and mental role limitations, food avoidance and sexual relations. There was no statistical difference between patients with IBS with diarrhea- or constipation-predominant symptoms.

Combining reassurance and patient education, diet management, probiotics administration and regular exercise in a health program improves symptoms and quality of life in patients with IBS.

\section{Introduction}

Irritable bowel syndrome (IBS) is a chronic condition that is characterized by abdominal discomfort or pain, altered bowel habits, and often bloating and abdominal distension. The degree of symptoms varies in different patients from tolerable to severe, interfering with daily activity. ${ }^{1}$ Estimates of prevalence of IBS varies from $12-30 \%$ but using recent diagnostic criteria it appears to affect $5-10 \%$ of individuals worldwide. ${ }^{2-14}$ IBS is more common in women than in men and more commonly diagnosed in patients under the age of 50 years. $^{2 \cdot 14}$

IBS reduces quality of life to the same degree of impairment as major chronic diseases such as congestive heart failure, hepatic cirrhosis, renal insufficiency and diabetes..$^{15-18}$ In an international survey, ${ }^{19}$ patients with IBS have reported impaired health status, restriction of daily activities for an average 73 days in a year, having poor health-related quality of life, particularly with regard to dietary restrictions, mood disturbance, and interference with daily activity. Furthermore, this survey showed that these patients would give up $25 \%$ of their remaining life (average 15 years) and 14\% would risk a 1/1000 chance of death to receive a treatment that would make them symptom free.

Although a minority (10-50\%) of IBS patients seek healthcare, they generate a substantial workload in both primary and secondary care.$^{6-8}$ It is estimated that $12-14 \%$ of primary care patient visits, and $28 \%$ of referrals to gastroenterologists are IBS patients, making this a more common reason for a visit to a physician than diabetes, hypertension or asthma. ${ }^{20-22}$ Not only do IBS patients visit doctors more frequently, but they also undergo more diagnostic tests, consume more medications, miss more days at work, have lower work productivity, are hospitalized more frequently, and consume more overall direct costs than those without IBS. ${ }^{14}$ The annual costs in the USA (both direct and indirect) to manage patients with IBS are estimated at 15-30 billion US dollars. ${ }^{6,23,24}$

Conventional therapy for IBS has focused on systematic relief of symptoms such as pain, diarrhea and constipation. Evidence of the long-term benefit of pharmacological agents has been sparse and new agents which proved to be affective have raised issues concerning safety. ${ }^{25,26}$ Not surprisingly, other alternative therapies have been considered. Thus, cognitive behavior therapy and gut-directed hypnotherapy have been used with good results. ${ }^{27}$ Other non-pharmacological approaches have also been tried with proved effect on symptoms and quality of life in patients with IBS. $^{27}$ Providing reassurance and information to
Correspondence: Magdy El-Salhy, Section for Gastroenterology, Department of Medicine, Stord Helse-Fonna Hospital, Stord, Norway.

E-mail: magdy.el-salhy@helse-fonna.no

Key words: irritable bowel syndrome, symptom score, quality of life, probiotics, reassurance.

Conflict of interest: the authors report no conflicts of interest.

Contributions: ME-S, designed the study, was responsible for the care of the patients, analysis of the data and wrote the article; EL, AR and LS, contributed to the care of the patients, analysis of the data and in the intellectual content of the study; TH, contributed to the design of the study, analysis of the data and writing of the article.

Acknowledgments: we would like to express our gratitude to Professor Hans Olav Fadnes, Head of the Department of Medicine, Stord Helse-Fonna Hospital for his support and for reading the manuscript. The authors wish to thank Dr. A.K. Roalfe for his kind permission to use the Birmingham IBS symptom score questionnaire. This study was supported by a grant from Helse-Fonna.

Received for publication: 18 December 2009

Revision received: 7 February 2010.

Accepted for publication: 12 March 2010

This work is licensed under a Creative Commons Attribution 3.0 License (by-nc 3.0).

(C) Copyright M. El-Salhy et al., 2010

Licensee PAGEPress, Italy

Gastroenterology Insights 2010; 2:e6

doi:10.4081/gi.2010.e6

patients with IBS, ${ }^{28,29}$ diet management, ${ }^{30,31}$ administration of probiotics, and regular exercise have each been found to reduce symptoms and improve quality of life. ${ }^{32-34}$

Against this background, the present study was undertaken to establish the effects of a health program comprising reassurance and patient information, diet management, administration of probiotics and regular exercise on symptoms and quality of life in patients with IBS.

\section{Materials and Methods}

\section{Patients}

Patients were recruited from those who were referred to the gastroenterology section, Stord Helse-Fonna Hospital from January 2006 to February 2008. Patients between 18 and 60 years of age who satisfied Rome III criteria for the diagnosis of IBS were considered for inclusion in the study. ${ }^{35}$ Those with organic gastrointestinal disease, clinically significant systemic diseases, and pregnant or lactating women 
were excluded. Patients who had undergone any abdominal surgery, with the exception of appendectomy, caesarean and hysterectomy, were also excluded. The study was performed in accordance with the Declaration of Helsinki and was approved by the local Committee for Medical Research Ethics. All patients gave oral and written consent.

\section{Study design}

The patients went through a program combining reassurance and IBS education, guidance in diet management, intake of probiotics and regular exercise. The patients were asked to complete the Birmingham IBS symptom score questionnaire, the SF-36 questionnaire and the IBS-quality of life (IBS-QOL) questionnaire before starting the program and three, six, 12 and 24 months after completing the program. The patients were allowed to use dimeticon (200 mg) tablets on demand. The program was carried out by a clinical team with special interests in IBS. This team consists of a senior gastroenterologist and 3 registered nurses.

\section{Reassurance and irritable bowel syndrome patient education}

Eligible patients had 2 one hour sessions with a gastroenterologist taken on 2 different occasions about a month apart. In the first session of about $60 \mathrm{~min}$, a full clinical history was taken and a thorough explanation was given of IBS diagnosis, the underlying mechanism of the disease, prognosis, and pharmacological and non-pharmacological treatment possibilities, with an emphasis on the treatment included in the program. This information was given in oral and written form. In the second session, a 15 min summary of the same information was given. Moreover, in this session a complete physical examination was performed and blood tests were taken to exclude liver, pancreas, kidney, endocrine or blood diseases. Gastroscopy with duodenal biopsies to exclude celiac disease and colonoscopy with biopsies to exclude microscopic colitis were performed on separate occasions.

\section{Guidance on diet management}

The patients were asked to keep a diet diary for at least a month. In this diary they wrote the time and kind of food and drinks they ingested daily. They also noted occurrence of pain, abdominal distension, as well as stool frequency and consistency. Symptoms were graded as light, moderate or severe. Two sessions with a registered nurse were scheduled of about an hour each. In the first session, the information given earlier by the gastroenterologist was repeated in a 20 min summary, emphasizing the role of diet. This information was given orally using charts and illustrative drawings. In the remaining $40 \mathrm{~min}$, the nurse examined the diet diary together with the patient. Diet instructions focused on the fibre content of the diet (soluble and non-soluble), identification of any food intolerances, regular meals and healthy eating habits. Together with the patient, the nurse outlined a diet that was suitable for the patient to try in the following month. A new diet diary was kept by the patient for the next session which was conducted in the same way as the first.

\section{Probiotics intake}

The patients were asked to take a course of the commercially available probiotics, Idoform balance $^{\circledast}$, at least twice a year. Each course lasted two months. Two patients reported a relapse of the IBS symptoms when they stopped ingesting probiotics. These patients took probiotics continually under the study.

\section{Regular exercise}

The patients were advised to exercise regularly at least 3 times a week. Exercise instruction emphasized involvement in aerobic activity, such as walking.

\section{Probiotic preparation}

The commercially available probiotic preparation, Idoform balance ${ }^{\circledR}$ from Ferrosan Norge AS was used. This probiotic preparation is in tablet form and contains $10^{9}$ colony-forming units (CFU) LGG Lactobacillus rhamnosus $\mathrm{GG} \circledR$ and $10^{9} \mathrm{CFU}$ Bifdobacterium, BB- $12^{\circledR}$.

\section{Irritable bowel syndrome symptom assessment}

The Birmingham IBS symptom score questionnaire was used in assessment of patients with IBS. This questionnaire has been developed to be suitable for self-completion and has been found to be acceptable to patients, and its dimensions have good reliability, external validity and sensitivity. ${ }^{36}$ The Birmingham IBS symptom score comprises questions based on the frequency of IBS symptoms. Each question had a standard response scale with symptoms all being measured on a 6 -point Likert scale ranging from $0=$ "none of the time" to $5=$ "all of the time". This questionnaire has 3 underlying dimensions: pain (3 items), diarrhea (5 items) and constipation (3 items).

\section{Assessment of quality of life}

The quality of life in patients with IBS was assessed by the SF-36 questionnaire and the IBS-quality of life (IBS-QOL) questionnaire.

The SF-36 is a 36 -item questionnaire that consists of 8 health concepts. Each concept is made up of a number of distinct questionnaire items. The 8 health concepts are: physical functioning (10 items), role limitations-physical (4 items), body pain (2 items), general health (5 items), vitality (4 items), social func- tioning (2 items), role limitations-emotional (3 items), mental health (5 items) and reported health transition ( 1 item). ${ }^{37}$ Each of the concepts is reported as a score from 0 (worst possible) to 100 (best possible). The SF-36 questionnaire has been applied widely to clinical trials. Analyses of the physical and mental health scales of the SF-36 have demonstrated that they are capable of discriminating between healthy subjects and patients with moderate levels of psychiatric or physical illness. ${ }^{38-41}$ SF-36 has been found to be not only sensitive to the presence of IBS, but also provides a useful tool for evaluating treatment outcomes for IBS. ${ }^{37}$

The IBS-quality of life (IBS-QoL) questionnaire is a 34-item disease-specific quality-oflife document concerning physical and psychosocial functioning as a result of IBS. ${ }^{42}$ This questionnaire consists of 8 domains: dysphoria, interference with activity, body image, health worry, food avoidance, social reaction, sexual function, and impact on relations.

\section{Statistical analysis}

The Kruskal-Wallis non-parametric ANOVA test and Dunn's post-test were used. P-values $<0.05$ were considered significant.

\section{Results}

\section{Patients}

A total of 180 patients were enrolled in the study. Of these patients, 11 were excluded because of celiac disease (6), microscopic colitis (2), Chron's disease (2) and colon carcinoma (1). Twenty-six patients dropped out. Of these 26,18 were females (mean age 30 years; range 18-40 years) and 8 were males (mean age 31 years; range 18-37 years). Thus, 143 patients satisfactorily completed the study: $95 \%$ were women and $5 \%$ were men. Patients were an average 32 years of age (range 18-58 years). Ninety-six of these patients had diarrhea as the predominant symptom and $47 \mathrm{had}$ constipation as the predominant symptom.

\section{Diet and exercise}

Examining the diet diary showed that patients with IBS in general did not tolerate gas-forming food such as beans, onions, celery, carrots, raisins and bananas. However, some tolerate a small amount of this food. Moreover, patients did not tolerate in various degrees wheat or wheat products. Under this program, some patients reported improvement of IBS symptoms with reduced consumption of fat, protein or carbohydrates. Others reported the opposite. All patients exercised at least $40 \mathrm{~min}$ 3 times a week. 


\section{IBS symptoms}

The total score of symptoms as assessed by the Birmingham IBS symptom questionnaire was decreased significantly three, six, 12 and 24 months after completing the program (Figure 1). All the 3 dimensions (pain, diarrhea and constipation) were diminished significantly after completing the program at all observation times.

\section{Quality of life}

The total score of quality of life as assessed by the SF-36 questionnaire was significantly improved in patients with IBS at all observation times after completing the program (Figure 2). It seems that the quality of life in patients with constipation as a predominant symptom has been improved more than those with diarrhea as a predominant symptom, but this difference was not statistically significant. Neither was there any difference between the 2 subtypes of IBS regarding all the SF-36 health concepts. There was a statistically significant improvement in all health concepts except in both physical and mental role limitation (Table 1).

The total score of quality of life as measured by the IBS-QoL questionnaire was significantly improved in patients with IBS three, six, 12 and 24 months after completing the program (Figure 3).

There was no statistical difference between patients with IBS with diarrhea- and constipation-predominant symptoms. All the domains were significantly improved except food avoidance and sexual relations (Table 2). There was no statistical difference between patients with diarrhea- or constipation-predominant symptoms as regards all domains.

\section{Discussion}

In the present study, a health program combining 4 different non-pharmacological approaches was used. Each of them showed improvement in the symptoms and quality of life of patients with IBS. These approaches are reassurance and patient education, diet management, probiotics administration and regular exercise. The program required relatively low resources, namely two hours consultation with a physician and two hours consultation with a nurse, as well as a gastroscopy and colonoscopy. The present findings clearly show an improvement in symptoms and in the quality of life in patients with IBS who took part in this program. It is noteworthy, however, that the ratio of females to males was 19:1, which is much higher than the IBS gender ratio in the general population. ${ }^{2-14}$ One should be cautious, therefore, when applying the results and con-

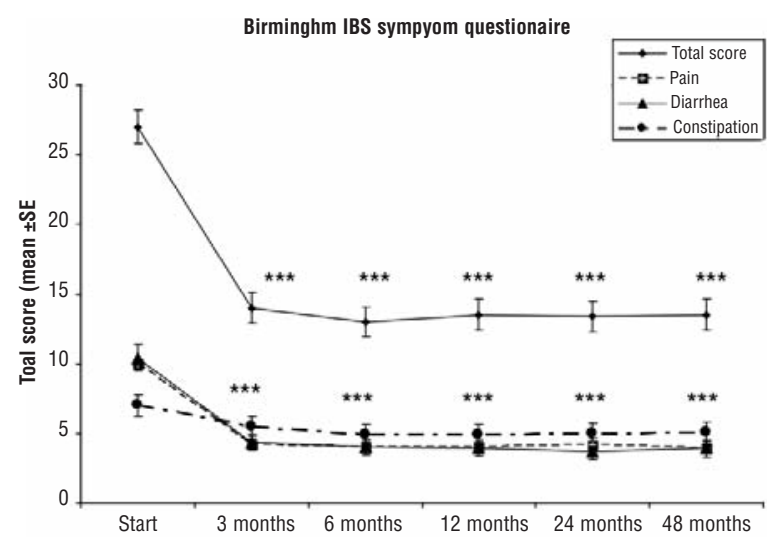

Figure 1. The total score and the 3 underlined dimensions: pain, diarrhea and constipation as assessed by the Birmingham IBS symptom score questionnaire. ${ }^{* * *}=\mathrm{P}<0.001$.
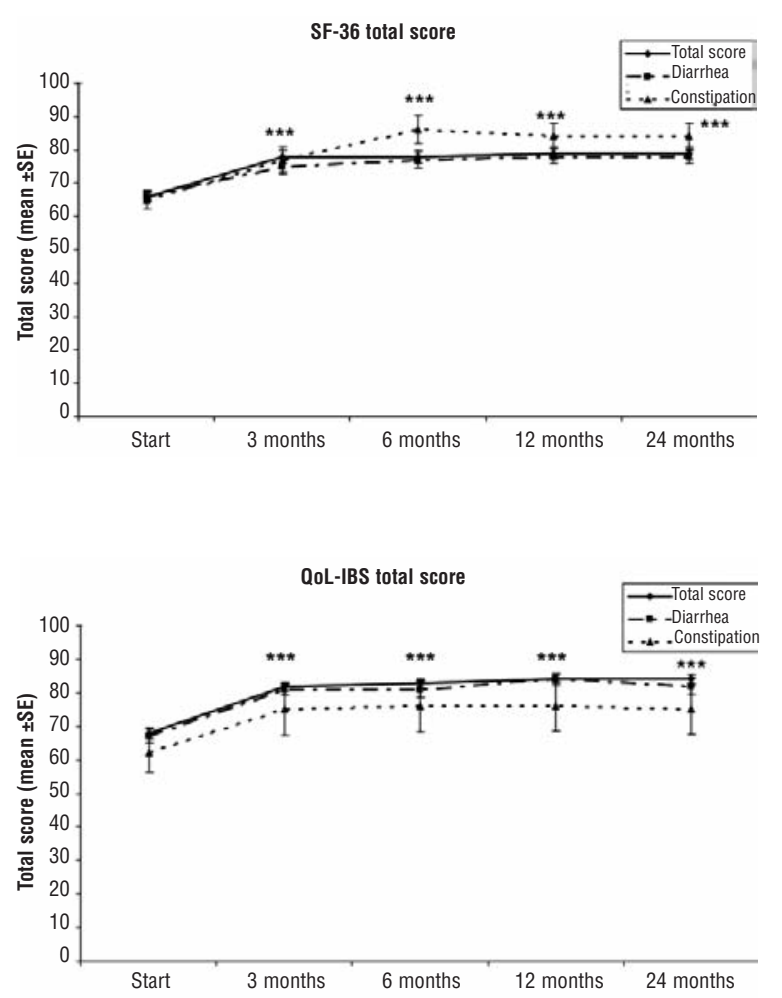

Figure 2. The total score of quality of life as revealed by the SF-36 questionnaire for all patients with IBS and for those with diarrheaand constipation-predominant symptom. ${ }^{* * *}=\mathbf{P}<\mathbf{0 . 0 0 1}$. Figure 3. The total score
of quality of life as
measured by the IBS-
quality of life question-
naire in the total of
patients with IBS and in
those with diarrhea and
constipation as the pre-
dominant symptom.
$* * *=\mathrm{P}<0.001$. clusions drawn here on male IBS patients.

An effective physician-patient relationship giving reassurance and providing a thorough explanation of the IBS disorder has been found to reduce the use of health care and diminishes the fear of cancer. ${ }^{43-45} \mathrm{~A}$ fifteen minute thorough oral explanation of the diagnosis and the underlying mechanism of IBS, and a complete physical examination by a gastroenterologist during the first consultation, reduced the selfperception of impairment in daily function. ${ }^{28}$ Furthermore, a structured 3-hour IBS educational class for patients with IBS has been reported to improve symptoms and some health-promoting behaviors. ${ }^{29}$ In the present program, a two hour thorough explanation with information about IBS was given by a gastroenterologist and a nurse. Moreover, in order to reassure the patients, a complete physical examination, blood tests, gastroscopy with biopsies and colonoscopy with biopsies were performed. The information given to the IBS patients in the present program fulfilled the 5 principles of effective patient education: i) relevant to the patient's need and abilities; ii) individualization; iii) feedback; iv) reinforcement; v) promoting a change in behavior. ${ }^{46,47}$

Most patients with IBS believe diet plays a significant role in their symptoms and $63 \%$ were interested in knowing what food to avoid. ${ }^{30}$ It has been shown that the IBS patients have non-specific diet intolerance. ${ }^{48}$ This lack of specificity causes considerable difficulty for IBS patients in choosing their diets. ${ }^{48}$ There is a marked difference in opinions about the role of diet in IBS symptoms. ${ }^{30}$ The present study has not been designed or aimed at studying the diet IBS patients tolerate, but at studying 
the effect of diet management. This study showed, however, that patients with IBS did not tolerate gas-forming food which is in accordance with other earlier observations. ${ }^{30}$ Moreover, patients did not tolerate wheat or wheat products, probably, as pointed out previously, due to the fructan level in wheat. ${ }^{30}$ Consumption of fat, protein and carbohydrates have been considered in association with IBS symptoms. ${ }^{30,49}$ Under this program, some patients reported improvement of IBS symptoms with reduced consumption of fat, protein or carbohydrates. Others reported the opposite. During the program, a considerable difference was found in food tolerability between patients and advice on diet management should, therefore, be given on an individual basis. There was no difference in food avoidance in patients with IBS before and after the program as revealed by the IBS-QOL questionnaire. This is not unexpected, as during the program food intolerance was identified and the patients were advised to avoid certain food. There is a difference, however, between food avoidance before and after the program: before the program, the patients avoided food and eating in general. After the program, they could adopt normal eating habits and avoid only some ingredients in the meals instead.

Probiotics alter colonic fermentation and stabilize colon microbiota, and several studies have shown an improvement in flatulence and abdominal distension with a reduction in composite IBS symptom score. ${ }^{32,33}$ Probiotics seem to enhance gut barrier function, inhibit pathogen binding and modulate gut inflammatory response. ${ }^{32,33}$ In the present program, a probiotic preparation containing Lactobacillus rhamnosus and Bifdobacterium was used. This choice was based on the fact that patients with IBS have fewer Lactobacillus spp. and Bifdobacterium spp. in their intestinal flora. ${ }^{33,50}$ Moreover, these bacteria have shown to bind to epithelial cells and inhibit pathogen binding, and to enhance barrier function. ${ }^{33}$ Furthermore, these bacteria spp. do not produce gas on fermenting carbohydrates, an effect which would be amplified as they also inhibit the Clostridia spp. $^{33}$ It is worthy of note that 2 patients observed a relapse of the IBS symptom as soon as they stopped taking the probiotic preparation. This observation made by the patients is in agreement with the finding that one week after stopping probiotic intake they vanished from feces. Although regular exercise has been found to reduce symptoms in patients with IBS, the physiological mechanisms still need to be explored. ${ }^{34}$

Placebo response rates are high in IBS, which make it difficult to detect the gain for therapeutic trials. ${ }^{51-54}$ Placebo response rate in IBS patients has been found to be $40.2 \% .{ }^{55}$ In contrast to that reported in ulcerative colitis patients, a lower placebo response correspond-
Table 1. The scores of the 8 health concepts of the SF-36 questionnaire before and after finishing the health program.

\begin{tabular}{|c|c|c|c|c|c|}
\hline & Start & 3 months & 6 months & 12 months & 24 months \\
\hline $\begin{array}{l}\text { Physical functioning } \\
\text { Total } \\
\text { Diarrhea } \\
\text { Constipation }\end{array}$ & $\begin{array}{l}64 \pm 2.3 \\
69 \pm 2.6 \\
59 \pm 5.2\end{array}$ & $\begin{array}{l}79 \pm 2.4^{*} \\
83 \pm 4.1^{*} \\
76 \pm 6.8^{*}\end{array}$ & $\begin{array}{l}89 \pm 3.5^{* * *} \\
90 \pm 3.8^{* *} \\
98 \pm 2.5^{* * *}\end{array}$ & $\begin{array}{l}91 \pm 3.4^{* * *} \\
92 \pm 3.9^{* * *} \\
97 \pm 2.4^{* * *}\end{array}$ & $\begin{array}{l}95 \pm 2.1^{* * *} \\
99 \pm 0.8^{* * *} \\
98 \pm 2.5^{* * *}\end{array}$ \\
\hline $\begin{array}{l}\text { Social functioning } \\
\text { Total } \\
\text { Diarrhea } \\
\text { Constipation } \\
\end{array}$ & $\begin{array}{l}64 \pm 2.2^{*} \\
66 \pm 2.4 \\
60 \pm 4.3\end{array}$ & $\begin{array}{l}78 \pm 9.2^{* * *} \\
79 \pm 3^{*} \\
77 \pm 5.5^{*}\end{array}$ & $\begin{array}{l}84 \pm 5.2^{* * *} \\
83 \pm 2.8^{*} \\
87 \pm 4.2^{*}\end{array}$ & $\begin{array}{l}85 \pm 4.2^{* * *} \\
83 \pm 2.8^{*} \\
87 \pm 4.3^{*}\end{array}$ & $\begin{array}{l}88 \pm 4^{* * *} \\
84 \pm 2.8^{* *} \\
75 \pm 6.9^{*}\end{array}$ \\
\hline $\begin{array}{l}\text { Role limitations-physical } \\
\text { Total } \\
\text { Diarrhea } \\
\text { Constipation }\end{array}$ & $\begin{array}{l}80 \pm 2.4 \\
81 \pm 2.3 \\
77 \pm 6.7\end{array}$ & $\begin{array}{l}90 \pm 2 \\
86 \pm 3 \\
95 \pm 1.6\end{array}$ & $\begin{array}{l}90 \pm 2 \\
88 \pm 3 \\
94 \pm 2.4\end{array}$ & $\begin{array}{l}88 \pm 2.8 \\
86 \pm 3.6 \\
94 \pm 2.4\end{array}$ & $\begin{array}{l}90 \pm 2.4 \\
85 \pm 3.5 \\
94 \pm 2.4\end{array}$ \\
\hline $\begin{array}{l}\text { Body pain } \\
\text { Total } \\
\text { Diarrhea } \\
\text { Constipation }\end{array}$ & $\begin{array}{l}54 \pm 2.8 \\
51 \pm 3.3 \\
60 \pm 5.3\end{array}$ & $\begin{array}{l}28 \pm 3^{* * *} \\
27 \pm 3.2^{* *} \\
32 \pm 8.4\end{array}$ & $\begin{array}{l}27 \pm 3^{* * *} \\
25 \pm 3.5^{* * *} \\
27 \pm 5.3\end{array}$ & $\begin{array}{l}26 \pm 2.6^{* * *} \\
26 \pm 3.5^{* *} \\
27 \pm 5.3\end{array}$ & $\begin{array}{l}28 \pm 3.2^{* * *} \\
28 \pm 4^{* *} \\
30 \pm 3.3\end{array}$ \\
\hline $\begin{array}{l}\text { General medical health } \\
\text { Total } \\
\text { Diarrhea } \\
\text { Constipation }\end{array}$ & $\begin{array}{l}53 \pm 2.9 \\
52 \pm 4 \\
45 \pm 4.6\end{array}$ & $\begin{array}{l}74 \pm 2.7^{* *} \\
73 \pm 3.9 \\
76 \pm 5.3\end{array}$ & $\begin{array}{l}74 \pm 2.7^{* *} \\
73 \pm 4 \\
78 \pm 4.9\end{array}$ & $\begin{array}{l}75 \pm 2.9 * * \\
73 \pm 4 \\
76 \pm 5.3\end{array}$ & $\begin{array}{l}77 \pm 3^{* * *} \\
74 \pm 4.5 \\
78 \pm 4.9\end{array}$ \\
\hline $\begin{array}{l}\text { Mental health } \\
\text { Total } \\
\text { Diarrhea } \\
\text { Constipation } \\
\end{array}$ & $\begin{array}{l}64 \pm 2.9 \\
61 \pm 4.4 \\
58 \pm 8.3\end{array}$ & $\begin{array}{l}88 \pm 2.7^{* *} \\
91 \pm 4.8^{* *} \\
78 \pm 10\end{array}$ & $\begin{array}{l}92 \pm 2.7 * * * \\
93 \pm 3.9^{* *} \\
78 \pm 10\end{array}$ & $\begin{array}{l}92 \pm 2.9 * * * \\
93 \pm 3.9^{* *} \\
86 \pm 9\end{array}$ & $\begin{array}{l}91 \pm 3^{* * *} \\
92 \pm 3.9 * * \\
86 \pm 9\end{array}$ \\
\hline $\begin{array}{l}\text { Role limitations- emotional } \\
\text { Total } \\
\text { Diarrhea } \\
\text { Constipation }\end{array}$ & $\begin{array}{l}37 \pm 5 \\
37 \pm 5 \\
52 \pm 11\end{array}$ & $\begin{array}{l}16 \pm 5 \\
12 \pm 5 \\
17 \pm 8\end{array}$ & $\begin{array}{r}13 \pm 4 \\
14 \pm 4 \\
9 \pm 4\end{array}$ & $\begin{array}{r}12 \pm 4 \\
10 \pm 4 \\
9 \pm 4\end{array}$ & $\begin{array}{r}12 \pm 4 \\
9 \pm 3 \\
9 \pm 4\end{array}$ \\
\hline $\begin{array}{l}\text { Vitality } \\
\text { Total } \\
\text { Diarrhea } \\
\text { Constipation }\end{array}$ & $\begin{array}{l}56 \pm 2 \\
56 \pm 3 \\
56 \pm 3\end{array}$ & $\begin{array}{l}71 \pm 2^{* *} \\
72 \pm 3^{* *} \\
70 \pm 4^{*}\end{array}$ & $\begin{array}{l}73 \pm 2^{* * *} \\
71 \pm 3^{*} \\
73 \pm 6^{*}\end{array}$ & $\begin{array}{l}73 \pm 2^{* * *} \\
72 \pm 3^{* *} \\
74 \pm 5^{*}\end{array}$ & $\begin{array}{l}74 \pm 2^{* * *} \\
73 \pm 3^{* *} \\
74 \pm 5^{*}\end{array}$ \\
\hline
\end{tabular}

All values expressed as mean $+\mathrm{SE}$. ${ }^{*} \mathrm{P}<0.05,{ }^{*} \mathrm{P}<0.01,{ }^{* *} \mathrm{P}<0.001$.

Table 2. The scores of the 8 domains of the IBS quality of life questionnaire before and after finishing the health program.

\begin{tabular}{|c|c|c|c|c|c|}
\hline & Start & 3 months & 6 months & 12 months & 24 months \\
\hline $\begin{array}{l}\text { Dysphoria } \\
\text { Total } \\
\text { Diarrhea } \\
\text { Constipation }\end{array}$ & $\begin{array}{l}38 \pm 2 \\
37 \pm 2.3 \\
45 \pm 6.8\end{array}$ & $\begin{array}{l}24 \pm 2.2 * * \\
23 \pm 2.2^{*} \\
25 \pm 7.9 *\end{array}$ & $\begin{array}{l}22 \pm 2.2^{* * *} \\
21 \pm 2.3^{* * *} \\
24 \pm 8^{* * *}\end{array}$ & $\begin{array}{l}20 \pm 1.9 * * * \\
19 \pm 2 * * * \\
26 \pm 7.4^{* * *}\end{array}$ & $\begin{array}{l}20 \pm 1.9^{* * *} \\
19 \pm 2.1^{* * *} \\
26 \pm 7.4^{* * *}\end{array}$ \\
\hline $\begin{array}{l}\text { Interference with activity } \\
\text { Total } \\
\text { Diarrhea } \\
\text { Constipation }\end{array}$ & $\begin{array}{l}30 \pm 2.1 \\
27 \pm 2.3 \\
46 \pm 6.8\end{array}$ & $\begin{array}{l}20 \pm 1.9^{*} \\
24 \pm 2.2^{*} \\
25 \pm 8^{*}\end{array}$ & $\begin{array}{l}17 \pm 1.7^{* *} \\
21 \pm 2.3^{* * *} \\
25 \pm 8^{*}\end{array}$ & $\begin{array}{l}17 \pm 1.8^{* * *} \\
19 \pm 2.1^{* * *} \\
26 \pm 7.4^{*}\end{array}$ & $\begin{array}{l}16 \pm 1.6^{* * *} \\
19 \pm 2 * * * \\
26 \pm 7.4^{*}\end{array}$ \\
\hline $\begin{array}{l}\text { Body image } \\
\text { Total } \\
\text { Diarrhea } \\
\text { Constipation }\end{array}$ & $\begin{array}{l}63 \pm 2.4 \\
65 \pm 2.7 \\
59 \pm 6.4\end{array}$ & $\begin{array}{l}76 \pm 2.5^{*} \\
77 \pm 2.6^{*} \\
74 \pm 8.9^{*}\end{array}$ & $\begin{array}{l}77 \pm 2.3^{* *} \\
78 \pm 2.6^{*} \\
74 \pm 8.8^{*}\end{array}$ & $\begin{array}{l}77 \pm 2.2^{* *} \\
78 \pm 2.5^{*} \\
73 \pm 8.3^{*}\end{array}$ & $\begin{array}{l}77 \pm 2.1^{*} \\
77 \pm 2.5^{*} \\
73 \pm 8.3^{*}\end{array}$ \\
\hline $\begin{array}{l}\text { Health worry } \\
\text { Total } \\
\text { Diarrhea } \\
\text { Constipation }\end{array}$ & $\begin{array}{l}33 \pm 2.5 \\
27 \pm 2.7 \\
35 \pm 6.8\end{array}$ & $\begin{array}{l}22 \pm 1.9 * \\
23 \pm 2.4 \\
18 \pm 6.3\end{array}$ & $\begin{array}{l}19 \pm 2 * * * \\
20 \pm 2.2 \\
18 \pm 6.3\end{array}$ & $\begin{array}{l}18 \pm 1.9 * * * \\
19 \pm 2.2 \\
20 \pm 5.7\end{array}$ & $\begin{array}{l}22 \pm 2.1^{*} \\
19 \pm 2.4 \\
20 \pm 5.6\end{array}$ \\
\hline $\begin{array}{l}\text { Food avoidance } \\
\text { Total } \\
\text { Diarrhea } \\
\text { Constipation }\end{array}$ & $\begin{array}{l}52 \pm 3.2 \\
47 \pm 4.8 \\
44 \pm 9.2\end{array}$ & $\begin{array}{l}53 \pm 3.2 \\
48 \pm 6.2 \\
43 \pm 9.9\end{array}$ & $\begin{array}{l}56 \pm 3.2 \\
55 \pm 6 \\
48 \pm 12\end{array}$ & $\begin{array}{l}56 \pm 3.3 \\
56 \pm 6.5 \\
48 \pm 10.3\end{array}$ & $\begin{array}{l}56 \pm 3.4 \\
53 \pm 6.7 \\
48 \pm 10.3\end{array}$ \\
\hline $\begin{array}{l}\text { Social reaction } \\
\text { Total } \\
\text { Diarrhea } \\
\text { Constipation }\end{array}$ & $\begin{array}{l}68 \pm 2.6 \\
68 \pm 3 \\
65 \pm 7.7\end{array}$ & $\begin{array}{l}81 \pm 1.9^{* *} \\
83 \pm 1.8^{*} \\
74 \pm 10\end{array}$ & $\begin{array}{l}83 \pm 1.9 * * \\
84 \pm 1.8^{* *} \\
76 \pm 10\end{array}$ & $\begin{array}{l}83 \pm 1.9 * * * \\
84 \pm 1.9 * * \\
74 \pm 9.3\end{array}$ & $\begin{array}{l}81 \pm 2.5^{* *} \\
84 \pm 2^{*} \\
74 \pm 9.3\end{array}$ \\
\hline $\begin{array}{l}\text { Sexual relations } \\
\text { Total } \\
\text { Diarrhea } \\
\text { Constipation }\end{array}$ & $\begin{array}{l}76 \pm 2.7 \\
78 \pm 4.7 \\
56 \pm 7.8\end{array}$ & $\begin{array}{l}87 \pm 2 \\
90 \pm 2.8 \\
80 \pm 10.7\end{array}$ & $\begin{array}{l}87 \pm 2 \\
91 \pm 2.6 \\
86 \pm 8.4\end{array}$ & $\begin{array}{l}87 \pm 2 \\
90 \pm 2.5 \\
96 \pm 8.4\end{array}$ & $\begin{array}{l}88 \pm 2 \\
90 \pm 2.5 \\
96 \pm 8.4\end{array}$ \\
\hline $\begin{array}{l}\text { Relations } \\
\text { Total } \\
\text { Diarrhea } \\
\text { Constipation }\end{array}$ & $\begin{array}{l}78 \pm 2.3 \\
79 \pm 2.2 \\
74 \pm 6\end{array}$ & $\begin{array}{l}88 \pm 2^{*} \\
92 \pm 1.4^{* * *} \\
81 \pm 9.1\end{array}$ & $\begin{array}{l}90 \pm 2 * * * \\
91 \pm 1.7 * * * \\
82 \pm 9.4\end{array}$ & $\begin{array}{l}90 \pm 1.9^{* * *} \\
92 \pm 1.7^{* * *} \\
79 \pm 8.9\end{array}$ & $\begin{array}{l}90 \pm 1.9 * * * \\
91 \pm 1.7^{* * *} \\
79 \pm 8.9\end{array}$ \\
\hline
\end{tabular}

All values expressed as mean $\pm \mathrm{SE}$. ${ }^{*} \mathrm{P}<0.05,{ }^{* *} \mathrm{P}<0.01,{ }^{* *} \mathrm{P}<0.001$ 
ed with an increasing number of visits to the surgery. ${ }^{55,56}$ These findings are counterintuitive as clinical experience shows that a strong patient-doctor relationship improves clinical outcome. Re-examination of this finding, however, has proven its accuracy. ${ }^{55}$ All placebo effects eventually wear of but they can last for a long time; up to two and half years for rheumatoid arthritis. ${ }^{57}$ To what extent the improved symptoms and quality of life seen in this study are due to placebo effect is hard to say. Assuming that the positive effects of the present program is due mainly to placebo effect, one cannot afford to dispense with a treatment that works, even if we are not certain how this happens. ${ }^{58}$

\section{References}

1. Thompson WG. A world view of IBS. In Camilleri M, Spiller R eds: Irritable bowel syndrome: Diagnosis and treatment. Philadelphia and London: Saunders; 2002, pp17-26.

2. Agreus L, Svarsudd K, Nygren 0, Tibblin G. Irritable bowel syndrome and dyspepsia in general population: overlap and lack of stability over time. Gastroenterology 1995; 109:671-80.

3. Thompson WG, Haeton KW. Functional bowel disorders in apparently healthy people. Gastorenterology 1980;79:283-8.

4. Kennedy TM, Jones RH, Hungin AP, et. Irritable bowel syndrome, gastrooesophageal reflux, and bronchial hyperresponsiveness in the general population. Gut 1998;43:770-4.

5. Drossman DA, Li Z, Andruzzi E, et al. U.S. householder survey of functional gastrointestinal disorders. Prevalence, sociodemography, and health impact. Dig Dis Sci 1993;38:1569-80.

6. Talley NJ, Gabriel SE, Harmsen WS, et al. Medical costs in community subjects with irritable bowel syndrome. Gastroenterology 1995;109:1736-41.

7. Hugin AP, Whonwell PJ, Tack J, Mearin F. The prevalence, patterns and impact of irritable bowel syndrome: an international survey of 40,000 subjects. Alment Pharmacol Ther 2003;17:643-50.

8. Jones R, Lydeard S. Irritable bowel syndrome in the general population. BMJ 1992; 304:87-90.

9. Bordie AK. Functional disorders of the colon. J Indian Med Assoc 1972;58:451-6.

10. O`Keefe EA, Talley NJ, Zinsmeister AR, Jacobsen SJ. Bowel disorders impair functional status and quality of life in the elderly: a population-based study. J Biol Sci Med Sci 1995;50:M184-M189.

11. Everhart JE, Renault PF. Irritable bowel syndrome in office-based practice in the United States. Gastroenterology 1991;100: :998-1005.

12. Wilson S, Roberts L, Roalfe A, Bridge P, Sukhdev S. Prevalence of irritable bowel syndrome: a community survey. Br J Gen Pract 2004;54:495-502.

13. Harvey RF, Salih SY, Read AE. Organic and functional disorders in 2000 gastroenterology outpatients. Lancet 1983;1:632-4.

14. Spiegel BM. The burden of IBS: looking at metrics. Curr Gastroenterol Rep 2009;11: 265-9.

15. Whitehead WE, Burnett CK, Cook EW III, Taub E. Impact of irritable bowel syndrome on quality of life. Dig Dig Sci 1996;41: 2248-53.

16. Gralnek IM, Hays RD, Kilbourne A, Naliboff B, Mayer EA. The impact of irritable bowel syndrome on health related quality of life. Gastroenterology 2000;11:654-60.

17. Huerta-Icelo I, Hinojosa C, Santa Maria A, Schmulson M. Diferencias en la calidad de vida (CV) entre pacientes con sindrome de Intestino irritable (SII) y la poblacon mexicana evaluadas mediante el SF-36. Rev Mex Gastroenterol 2001;66:145-6.

18. Schmulson M, Robles G, Kershenobich D, Lopez-Ridaura R, Hinojosa C, Duarte, et al. Los pacientes con trastornos funcionales digestivos (TFD) tienen major compromiso de la calidad de vida (CV) evaluadas por el SF-36 comparados con pacientes con hepatitis $\mathrm{C}$ y pancreatitis cronica. Rev Mex Gastroenterol 2000;65 (SupplResumenes):50-1.

19. Drossman DA, Morris CB, Schneck S, et al. International survey of patients with IBS: symptom features and their severity, health status, treatments, and risk taking to achieve clinical benefit. J Clin Gastroenterol 2009;43:541-50.

20. Schuster MM. Defining and diagnosing irritable bowel syndrome. Am J Manag Care 2001;7:S246-251.

21. National ambulatory Medical Care Survey. National Center for Health Statistics: NAMCS Description. Available at: http://www.cdc.gov/nchs/about/major/ahcd/ namcsdes.htm.

22. Mitchel CM, Drossman DA. Survey of AGA membership relating to patients with functional gastrointestinal disorders. Gastroenterology 1987;92:1282-4.

23. American Gastroenterological association. The Burden of Gastrointestinal Diseases, Bethesda, MD, 2001.

24. Sandler RS, Everhart JE, Donowitz M, et al. The burden of selected digestive diseases in the United States. Gastroenterology 2002;122:1500-11.

25. Spanier JS, Howden CW, Jones MP. A systematic review of alternative therapies in irritable bowel syndrome. Arch Intern Med
2003;163:265-74.

26. Pasricha PJ. Desperately seeking serotonin: a commentary on the withdrawal of tegaserod and the state of functional and motility disorders. Gastroenterology 2007; 132:2287-90.

27. Wald A, Rakel D. Behavioral and complementary approaches for the treatment of irritable bowel syndrome. Nutr Clin Pract 2008;23:284-92.

28. Schmulson MJ, Ortiz-Garrido OM, Hinojosa C, Arcila D. A single session of reassurance can acutely improve the selfperception of impairment in patients with IBS. J Psychosom Res 2006;6:461-7.

29. Clowell LJ, Prather CM, Philips SF, Zinsmeister AR. Effects of an irritable bowel syndrome educational class on health-promoting behaviors and symptoms. Am J Gastroenterol 1998;93:901-5.

30. Heizer WD, Southern S, McGovern S. The role of diet in symptoms of irritable bowel syndrome in adults: a narrative review. $\mathrm{J}$ Am Diet Assoc 2009;109:1204-14.

31. Singh N, Makharia GK, Joshi YK. Dietary survey and total dietary intake in patients with irritable bowel syndrome attending a tertiary referral hospital. Indian $\mathrm{J}$ Gastroenterol 2008; 27:66-70.

32. Brenner DM, Moeller MJ, Chey WD, Schoenfeld PS. The utility of probiotics in the treatment of irritable bowel syndrome: a systematic review. Am J Gastroenterol 2009;104:1033-49.

33. Speller R. Review article: probiotics and prebiotics in irritable bowel syndrome. Alment Pharmacol Ther 2008;28:385-96.

34. Levy RL, Linde JA, Feld KA, Crowell MD, Jeffery RW. The association pf gastrointestinal symptoms with weight diet and exercise in weight-loss program participants. Clin Gastroenterol Hepatol 2005; 2:992-6.

35. Longstreth GF, Thompson WG, Chey WD, et al. Functional bowel disorder. Gastroenterology 2006;130:1480-91.

36. Roalfe AK, Roberts LM, Wilson S. Evaluation of the Birmingham IBS symptom questionnaire. BMC Gastroenterol 2008;8:30-6.

37. Bensoussan A, Chang SW, Menzies RG, Talley NJ. Application of the general status questionnaire SF36 to patients with gastrointestinal dysfunction: initial validation and validation as a measure of change. Aust N Z J Public Health 2001;25:71-7.

38. McCallum J. The SF-36 in an Australian sample: validating a new, generic health status measure. Aust J Public Health 1995;19:160-6.

39. Garrat AM, Ruta DA, Absalla MI, et al. The SF-36 health survey questionnaire: an outcome measure suitable for use within the NHS? Br Med J 1993;306:1440-4. 
40. McHorney CA, Ware JE, Raczek AE. The MOS 36-item short-form health survey (SF-36): II. Psychometric and clinical tests of validity in measuring physical and mental health constructs. Med Care 1993; 31:247-63.

41. McHorney CA, Ware JE, Lu JFR, Sherbourne CD. The MOS 36-item short-form health survey (SF-36): III. Tests of data quality, scaling assumptions, and reliability across diverse patient groups. Med Care 1994;32:44-66.

42. Drossman DA, Patrick DL, Whitehead WE, et al. Further validation of the IBS-QOL: a disease-specific quality-of-life questionnaire. Am J Gastroenterol 2000;95:9991007.

43. Whitehead WE, Bosmajian L, Zonderman AB, Costa PT, Shuster MM. Symptoms of psychological distress associated with irritable syndrome. Comparasion of community and medical clinical samples. Gastroenterolog 1988;95:709-14.

44. Fowlie S, Eastwood MA, Ford MJ. Irritable bowel syndrome: the influence of psychological factors on the symptom complex. J Psychosom Res 1992;36:169-73.

45. Thompson WG, Heaton KW, Smyth GT, Smyth C. Irritable bowel syndrome in gen- eral practice: prevalence characteristics and referral. Gut 2000;46:78-82.

46. Simons-Morton DG, Mullen PD, Mains DA, et al. Characteristics of controlled studies of patient education and counseling for preventive health behaviors. Patient Educ Couns 1992;19:175-204.

47. Mullen PD, Mains DA, Velez R. A meta analysis of controlled trials of cardiac patient education. Patient Educ Couns 1992;19:142-62.

48. Soares RL, Figueiredo MN, Maneschy CP, et al. Correlation between symptoms of the irritable bowel syndrome and the response to the food extracts skin prick test. Braz J Med Biol Res 2004;37:659-62.

49. Austin GL, Dalton CB, Hu Y, et al. A very low-carbohydrate diet improves symptoms and quality of life in diarrhoea-predominant irritable bowel syndrome. Clin Gastroenterol Hepatol 2009;7:706-8.

50. Kassinen A, Krogius-Kurikka L, Mäkivuokko H, et. al. The fecal microbiota of irritable bowel syndrome patients differs significantly from that of healthy subjects. Gastroenterology 2007;133:24-33.

51. Spiller RC. Problems and challenges in the design of irritable bowel syndrome trials: experience from published trials. Am J
Med 1999;107:915-75.

52. Jaiwala J, Imperiale TF, Kroenke K. Pharmacological treatment of the irritable bowel syndrome: a systematic review of randomized, controlled trials. Ann Intern Med 2000;133:136-47.

53. Thompson WG. Placebos: a review of the placebo response. Am J Gastroenterol 2000;95:1637-43.

54. Camilleri M, Talley NJ. Pathophysiology as a basis for understanding symptom complexes and therapeutic targets. Neurogastroenterol Motil 2004;16:135-42.

55. Patel SM, Stason WB, Legedza A, et al. The placebo effect in irritable syndrome trials: a meta-analysis. Neurogastroenterol Motil 2005; 17:332-40.

56. Inyckyj A, Shanahan F, Anton PA, et al. Quantification of the placebo response in ulcerative colitis. Gastroenterolgy 1997; 112:1854-8.

57. Traut EF, Passarelli EW. Placebos in the treatment of rheumatoid arthritis and other rheumatic conditions. Ann Rheum Dis 1957;16:18-22.

58. Spiegel D. Placebos in practice. BMJ 2004;329:927-8. 